\title{
Climate and land use changes as origin of the Water Cycle variations and sediment transport in Pesaro Urbino Province, Central and Eastern Italy
}

Cambiamenti climatici e dell'uso del suolo come origine delle variazioni del Ciclo dell'Acqua e del trasporto dei sedimenti nella Provincia di Pesaro Urbino, Italia Centro-orientale

\author{
Daniele Farina, Paolo Cavitolo
}

\begin{abstract}
Riassunto: Lo studio evidenzia una diminuzione significativa delle precipitazioni efficaci e del deflusso durante il periodo 1950-2010, che riguarda in particolare le stazioni montane ed il periodo invernale di surplus idrico. La variazione di deflusso è collegata anche ad una importante evoluzione dell'uso del suolo nelle aree montane, a causa di un progressivo processo di naturale rimboschimento. Il Flusso di base del f. Candigliano, alimentato dalla discarica sorgiva degli acquiferi carbonatici, è risultato più stabile, per effetto di una capacità degli acquiferi largamente superiore a quello delle acque invasate nei bacini superficiali. Tali invasi sono soggetti ad un marcato processo di interrimento, che è ancora attivo, come suggerito dai tassi di erosione determinati nei bacini, particolarmente elevati nel bacino del f. Foglia. Sono state considerate e valutate le importanti implicazioni relative alla mobilità dei sedimenti, alla affidabilità delle risorse superficiali, alle limitazioni inerenti il Deflusso Minimo Vitale, nonché alla efficacia dei progetti di sfangamento degli invasi. Nell'ottica di un necessario processo di adattamento al cambiamento climatico, lo studio suggerisce una graduale transizione dall'attuale uso preminente delle risorse idriche superficiali verso una integrazione su base stagionale delle risorse dinamiche degli acquiferi carbonatici, quale strategia sostenibile per il prossimo futuro.
\end{abstract}

Parole chiave: province of Pesaro-Urbino, runoff, minimum flow, carbonate aquifers, silting.

Keywords: provincia di Pesaro-Urbino, deflusso, deflusso minimo vitale, acquiferi carbonatici, interrimento.

\author{
Daniele FARINA 夆: \\ Consulting geologist \\ Studio Geologico Dr. Daniele Farina, Pesaro, Italy \\ E-mail: farinadaniele61@gmail.com \\ Paolo CAVITOLO \\ Consulting geologist \\ Geological Studio, Ancona, Italy
}

Ricevuto: 26 maggio 2016 / Accettato: 26 settembre 2016 Pubblicato online: 03 ottobre 2016

This is an open access article under the CC BY-NC-ND license: http://creativecommons.org/licenses/by-nc-nd/4.0/

(C) Associazione Acque Sotterranee 2016

\begin{abstract}
The study shows a significant net precipitation and surficial runoff decrease in the Province of Pesaro-Urbino during the 1950 2010 period, especially affecting mountain areas and the water-surplus winter season. Runoff variation is also related to a significant land use change, due to a progressive natural reafforestation process that has taken place in the mountain area. Candigliano river's base-flow, fed by carbonate aquifers' groundwater discharge, was found more stable over time, due to an aquifers' capacity largely exceeding that of existing surface reservoirs. The latter have been affected by a significant silting process, which is still active, as suggested by specific erosion rates of watersheds, particularly in the Foglia basin. Important implications both on sediment mobility, surface water-supply reliability, minimum flow constraints and effectiveness of volume-recovery projects of reservoirs were preliminarly evaluated. In the perspective of a necessary adaptation process to the climate change, the study suggests a gradual transition from the present prevailing use of surface water, to an integrated management of the carbonate aquifers' dynamic resources, on a seasonal base, as a sustainable strategy for the next future.
\end{abstract}

\section{Introduction}

The Province of Pesaro-Urbino (Area: $2564 \mathrm{~km}^{2}$, population $366,000)$ with the $75 \%$ of drink water supplies coming from rivers and/or small reservoirs, has been facing critical periods during the last two decades, due to the decreasing streamflow, poor water quality, besides high treatment costs and important impact on rivers' life during the dry season (Farina 2013). The Metauro-Candigliano watershed is characterised by the presence of important carbonate aquifers, whose average natural groundwater discharge (2000-2010) within the studied territory was estimated to be $50 \times 10^{6} \mathrm{~m}^{3} / \mathrm{y}$ (Farina and Severini 2013). Approximately only the $10 \%$ of such volume is directly diverted in public aqueducts and it is mostly represented by surficial springs (AATO1 Marche Nord 2010), while the rest feeds the Candigliano river and its tributaries, where most of surface water withdrawals takes place from small dams down valley (S. Lazzaro and Tavernelle reservoirs, see Fig. 1). The choice to resort to surface waters in the past decades (1980-2000) has shown its limits as the climate change' effects have gradually become evident, both in terms of increasing frequency of droughts and flood events (Ferrara 2007, Gentilucci et al. 2015). The latter are capable to mobilize significant volumes of sediments from rivers' beds 
and interfere with hydraulic infrastructures along their course, while droughts and heat waves frequently induce problems of algal blooming, besides overall water scarcity, poor quality, social alarm and potential water-use conflicts. Expensive restoration projects of reservoirs' capacity by sediments' excavation, have been recently carried out in order to increase water storage during drought periods. The duration of such solutions, beside their global effectiveness and environmental impact, should therefore be considered.

\section{Objectives}

The first objective of the study is the analysis of average precipitation and temperatures of the 1980-2010 period within the Province of Pesaro-Urbino and its variations compared to a previous time-series (1950-69), on which most of the water resources planning was based, especially during the seventies (Molinari et al. 1971, Pesaro-Urbino Province 1973). Those reference data represent the climate during a period of high socio-economic development, when most of the local water-supply infrastructures were designed and constructed (dams, weirs, aqueducts). The study is intended to depict the effects of climate change on the water cycle, in terms of runoff and net infiltration changes. The aim of such analysis is to develop a preliminary assessment of how runoff in the main catchments changed over time. Besides, since water and sediment fluxes strongly influence the rivers' dynamics and resident infrastructures, such as dams, the study presents preliminary results of sediments' load assessment in the main reservoirs of the Province. The assessment is meant to suggest up-to-date criteria to public regulators, especially intended to set new minimum flow constraints to specific river sections, where the impact of surface water withdrawals is particularly high. Besides, it sets some basic criteria and knowledge for a systemic and adaptative approach to waterresources planning in a changing climate and environment (European Commission 2012).

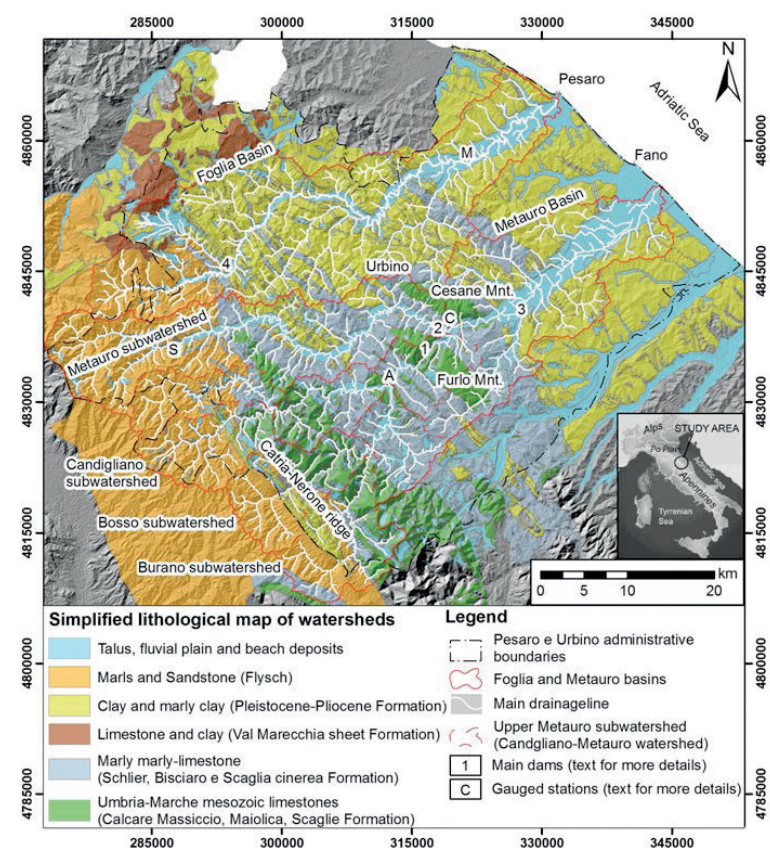

Fig. 1 - Simplified lithological map and watersheds (1: Furlo dam, 2: Calmazzo dam, 3: Tavernelle dam, 4: Mercatale dam, A: Acqualagna runoff-gauge station, C: Calmazzo station, S: S. Angelo in Vado station, M: Montecchio station).

Fig. 1 - Carta litologica semplificata e dei bacini idrografici (1: diga Furlo, 2: diga Calmazzo, 3: diga Tavernelle, 4: diga Mercatale, A: stazione di deflusso Acqualagna, C: stazione Calmazzo, S: stazione S. Angelo in Vado, M: stazione Montecchio).

\section{Materials and Methods}

The recent temperature and precipitation (P) data-set (Marche Region 2016) was compared to the 1921-49 and 195069 average on all rain-gauge stations of the territory (PesaroUrbino Province 1973, Centro di Ecologia e Climatologia di Macerata 2002). The 1950-69 series, with no significant variations with the previous one, was considered for its better data coverage and time-overlapping with the temperature data-set (1955-69). Mean yearly Actual Evapotranspiration (AE) was calculated using different methods (Turc 1955, Lu Zhang et al.2008). Monthly analysis of water surplus was taken from Farina and Severini, 2013: they applied the Thornthwaite method (Thornthwaite and Mather 1957), using the 1980-2010 climate data, where soil water-storage estimates were based on soil texture and thickness, taken from Armiraglio et al. (2003) and ASSAM (2006).

As for the runoff, the surface component, which is predominant in low-permeability basins such as Foglia and Metauro, was estimated: a) by regionalizing the Effective Precipitation (EP $=\mathrm{P}-\mathrm{AE})$ and attributing Potential Infiltration Coefficients (P.I.C., Civita 1973) to the different lithologies (Fig. 1), in order to estimate the Effective Infiltration Ie (Ie = EP x PIC) and therefore obtain surface runoff. P.I.C estimates of aquifers were carried out considering, within the values'range proposed by the author, not only the lithology, but also the morphology and overburden of bedrock. Precipitation, Evapotranspiration, total Runoff and Infiltration maps were elaborated by Cavitolo (2014) by means of GIS technology (www.qgis.org/it/). Runoff maps were elaborated selecting two main different methods for calculating AE : Turc and Budyko methods (in Lu Zhang et al. 2008), the latter considering the actual soil-use. A hydrological simulation was carried out by implementing the USDA Curve Number method on the WinHelp code (Waterloo Hydrologic 2004); that analysis requires climatic, morphologic and stratigraphic detailed information and its application was limited to a test-basin 


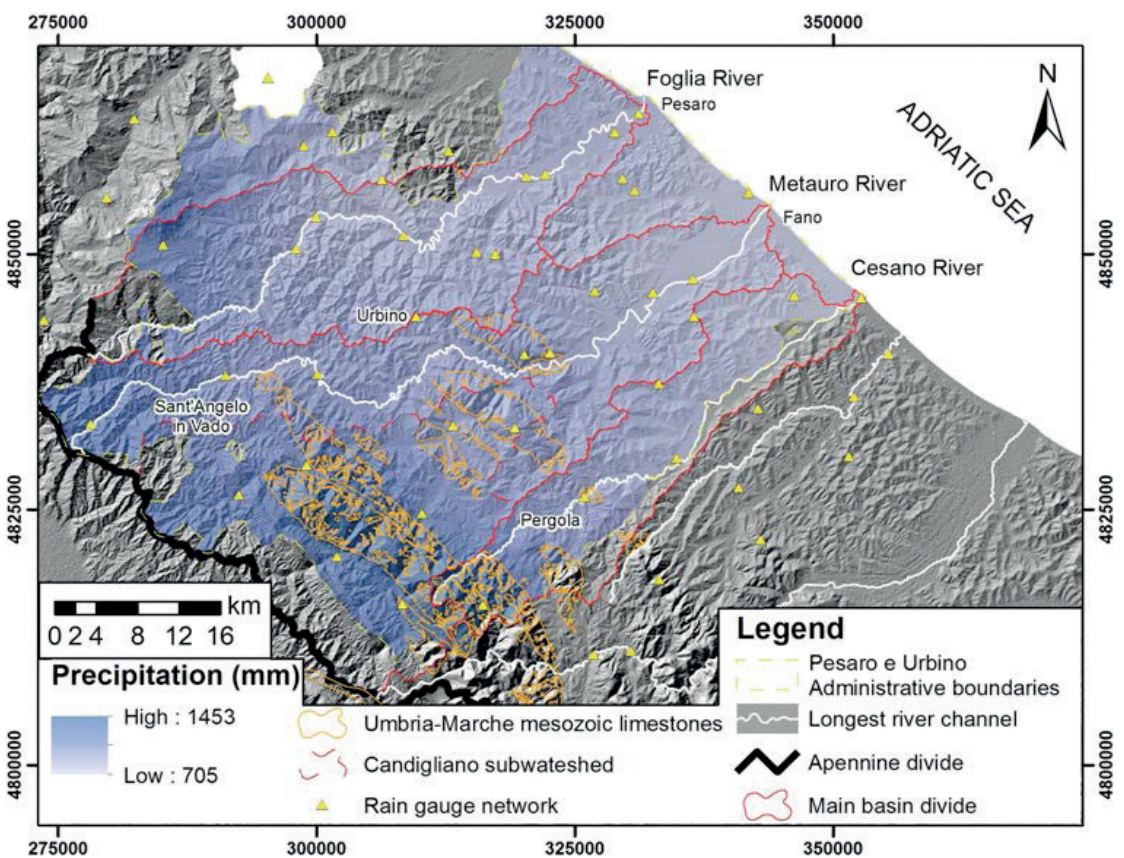

Fig. 2 - Precipitation and main watersheds map of the Province of Pesaro-Urbino (19802010).

Fig. 2 - Carta delle precipitazioni e dei bacini idrografici della Provincia di Pesaro-Urbino (1980-2010).

(upper Metauro subwatershed, section S. Angelo in Vado) in order to get comparative estimates. c) Effective Infiltration was also estimated by acquiring experimental data of rivers' base flow, based on a set of numerous direct measurements, carried out throughout the years by means of current-meters. Moreover, all available flow rate estimates from water springs abducted to public aqueducts were collected and attributed to the different aquifers (Farina and Severini 2013).

In particular, for the Candigliano river, the acquisition of some recent river discharge measurements taken from the Basin Authority of Marche Region, could be compared to older hydrometric data of the National Hydrographic service (SIMN), mainly within the 1921-1969/1975 period for most flow-gauge then in operation. To estimate summer base-flow, the average of monthly minimum runoff data of June, July and August were considered, so to better match the direct measures performed in the last decade.

A preliminary assessment or riverbed sediment load and basins' volume reduction was based on previous estimates (Gazzolo and Bassi 1961) and more recent determinations and methodologies, (CESI 2001, Rusco et al. 2009) and data from Consorzio di Bonifica (Unreleased report 2013) and AATO1. Specific suspended sediment load and Specific bed

load Transport (both in $\mathrm{m}^{3} / \mathrm{Km}^{2} / \mathrm{y}$ ) were then calculated, in order to characterize the different erosive conditions of the main basins. Last, based on direct estimates carried out by AATO1, basins' volume reduction was considered to evaluate on a preliminary and qualitative basis the tendency toward further sedimentation in such reservoirs.

\section{Results}

The analysis highlights an average precipitation decrease of 11.7\% between 1950-69 and 1980-2010 recent time series, calculated over the whole set of rain-gauge stations. The majority of stations in the mountain area show a precipitation decrease in the 12-21\% range (Tab. 1). Recent average precipitations range from $1450 \mathrm{~mm} / \mathrm{y}$ in the Catria-Nerone massif to $705 \mathrm{~mm} / \mathrm{y}$ in the south-eastern coast (Fig. 2). As for temperatures, a significant global and local warming has occurred, with a sharp increase of mean temperatures starting in the mid eighties (Fig. 3). A coherent trend was detected also in the Marche Region (ISPRA 2016).

Nevertheless, precipitation variations analysis vs. time evidences a fluctuation between drier and wetter periods, with a 9 to 13 years period. Starting in 2010, a recent increase in annual precipitation (2010-2015) is occurring (Fig. 4).

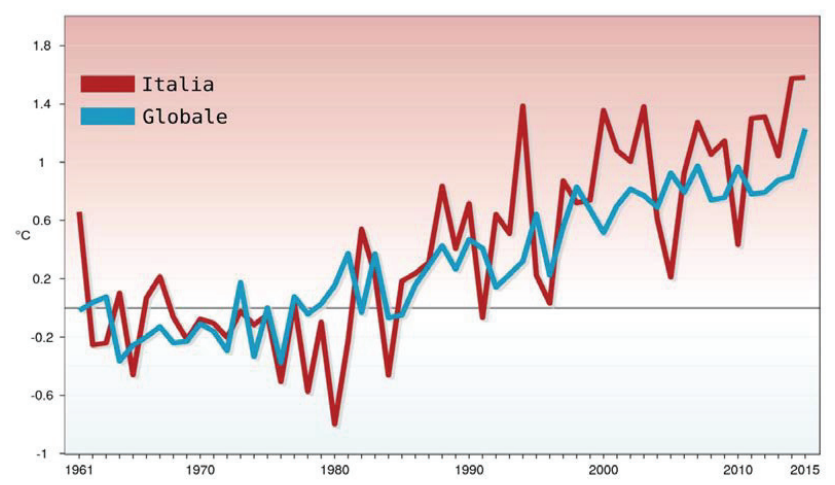

Fig. 3 - Mean Annual Temperature variation (1961-2015): global (blue), Italy (red)-from: ISPRA 2015.

Fig. 3 - Variazione della temperatura media annua (1961-2015): globale (blu), in Italia (rosso). 
Tab. 1 - Precipitations' variation, in \%, comparing 1950-69 and 1980-2010 (Farina 2013, modified).

Tab. 1 - Variazione delle precipitazioni, in \% tra le medie storiche 1950-'69 e 1980-2010 (Farina 2013, modificato).

\begin{tabular}{|c|c|c|c|c|}
\hline Rain-gauge station & $\begin{array}{c}\text { Mean precipitation } \\
1950-1969\end{array}$ & $\begin{array}{l}\text { Mean precipitation } \\
1980-2010\end{array}$ & Difference $\%$ & Geographic area \\
\hline Cantiano & 1354 & 1190 & -12.1 & \multirow{15}{*}{ Mountain and piedmont } \\
\hline Cagli & 1341 & 1092 & -18.6 & \\
\hline Pianello & 1334 & 1172 & -12.1 & \\
\hline Piobbico & 1289 & 1093 & -15.2 & \\
\hline Fonte Avellana & 1857 & 1453 & -21.7 & \\
\hline Pennabilli & 1115 & 1093 & -1.9 & \\
\hline Carpegna & 1214 & 1083 & -10.7 & \\
\hline Villagrande & 1155 & 1050 & -9.1 & \\
\hline Mercatello & 1205 & 1280 & +6.2 & \\
\hline S.Angelo in Vado & 1057 & 941 & -10.9 & \\
\hline Urbania & 1051 & 922 & -12.3 & \\
\hline Foresta Cesane & 1055 & 911 & -13.6 & \\
\hline Acqualagna & 997 & 885 & -11.3 & \\
\hline Pergola & 1017 & 862 & -15.2 & \\
\hline Fossombrone & 1000 & 869 & -13.1 & \\
\hline S.Lorenzo in C. & 911 & 791 & -13.2 & \multirow{9}{*}{ Outer hills } \\
\hline Barchi & 936 & 826 & -11.8 & \\
\hline Piagge & 905 & 780 & -13.9 & \\
\hline Petriano & 961 & 797 & -17.1 & \\
\hline Mondolfo & 844 & 709 & -16 & \\
\hline Sassocorvaro & 807 & 817 & +1.2 & \\
\hline Tavoleto & 931 & 726 & -22 & \\
\hline Urbino & 871 & 828 & -5 & \\
\hline Saludecio & 870 & 792 & -8.9 & \\
\hline Pesaro & 815 & 795 & -2.4 & \multirow{3}{*}{ Adriatic coast } \\
\hline Fano & 803 & 705 & -12.2 & \\
\hline Average variation & & & -11.7 & \\
\hline
\end{tabular}

\section{Rivers' surface runoff and effective infiltration}

First, the AE computations with different formulas showed a limited difference $( \pm 10 \%)$, with Turc's method giving an intermediate value among others (Cavitolo 2014). The maps of Fig. 5 show that most of the surface runoff is originated in low permeability mountain basins (upper Foglia and Metauro). The lowest values are pertinent to high permeability terrains, both on carbonate-karst reliefs within the Candigliano basin (Bosso and Burano sub-watershed of Fig. 1) and flat alluvial plains, both representing the main aquifers of the Province. Nevertheless alluvial plains are characterized by high $\mathrm{AE}$ and little water surplus, due to the different climatic setting of the lowlands. The performed analysis also shows a significant decrease of yearly average runoff in all basins. Comparing historical SIMN data and indirect estimates a decrease of approximately $-35 \%$ could be detected in the Foglia basin (Tab. 2). The result is in good agreement with previous estimates using the Kennessey method, where the decrease of the Runoff Coefficient was attributed both to the climate change and to a progressive reafforestation process that developed in the mountain area (Marchetti et al. 2012, Farina 2013). An even higher decrease is detected in the upper Metauro and Candigliano basins. Therefore a simulation of the Curve Number method was carried out in the low permeability upper Metauro test basin, using recent climate and land use data: that evidenced a surface runoff of $12.2 \mathrm{~L} / \mathrm{s} / \mathrm{km}^{2}$ together with a significant shallow infiltration of $6.5 \mathrm{~L} / \mathrm{s} / \mathrm{km}^{2}$ drained in the overburden deposits, connected to the valley alluvium (Fig. 6).

Experimental runoff estimates, although limited to the 2007-2010 period, show as well an important decrease of average year discharge in the Candigliano basin (Acqualagna section), compared to the historical dataset. Annual average runoff varied from $15.7 \mathrm{~m}^{3} / \mathrm{s}$ (13 years from 1924 to 1964 ) to $13.9 \mathrm{~m}^{3} / \mathrm{s}$ (22 years from 1924 to 1979 ) to the recent $8.7 \mathrm{~m}^{3} / \mathrm{s}$ (2007-2010), with a pertinent present average specific runoff of $14.1 \mathrm{~L} / \mathrm{s} / \mathrm{km}^{2}$ (Fig. 7). The recent record is insufficient, although the result is coherent with the observations of 

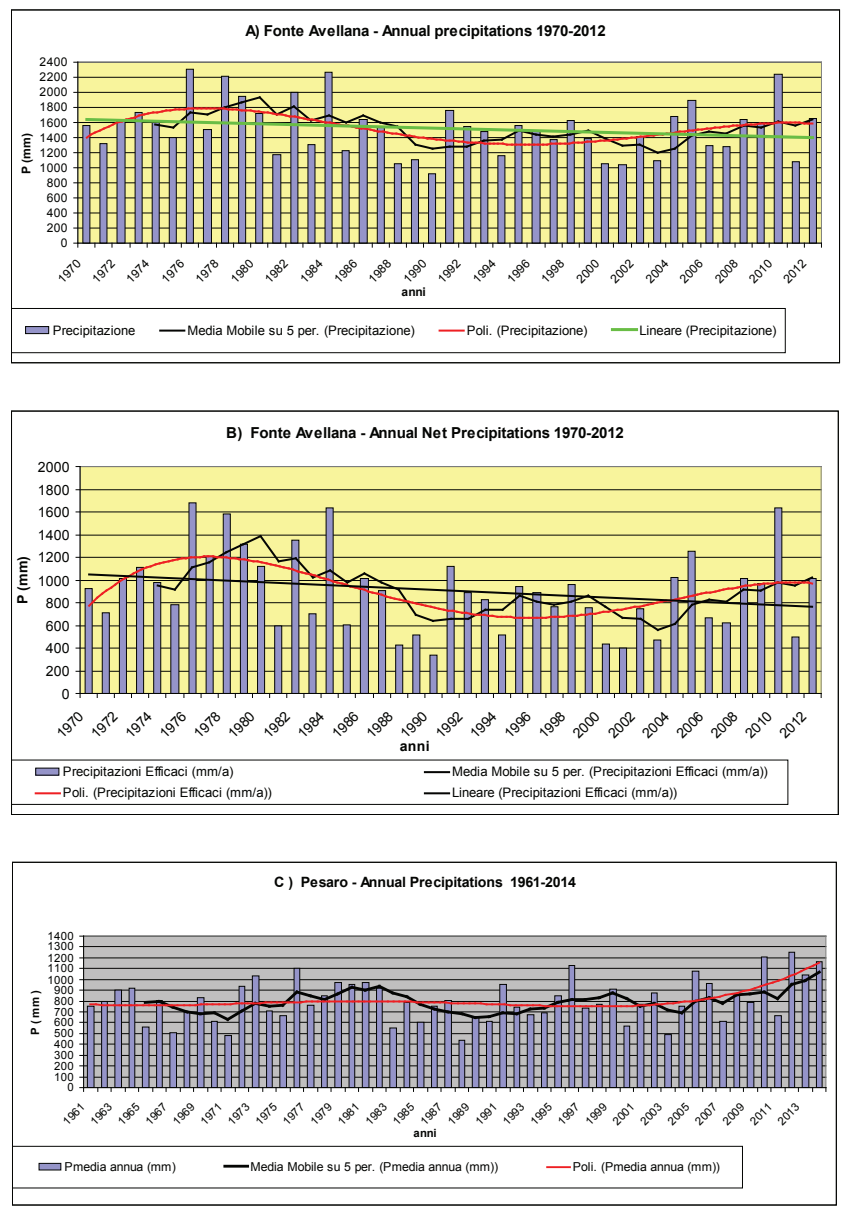

Fig. 4 - Total and net precipitation at F. Avellana $(A, B)$ and Pesaro (C) with interpolation curves. In $C)$ wet and dry periods are depicted.

Fig. 4 - Precipitazioni totali ed efficaci a F. Avellana (A e B) e Pesaro (C), con interpolazioni; periodi secchi (giallo) e piovosi (blu) a Pesaro.

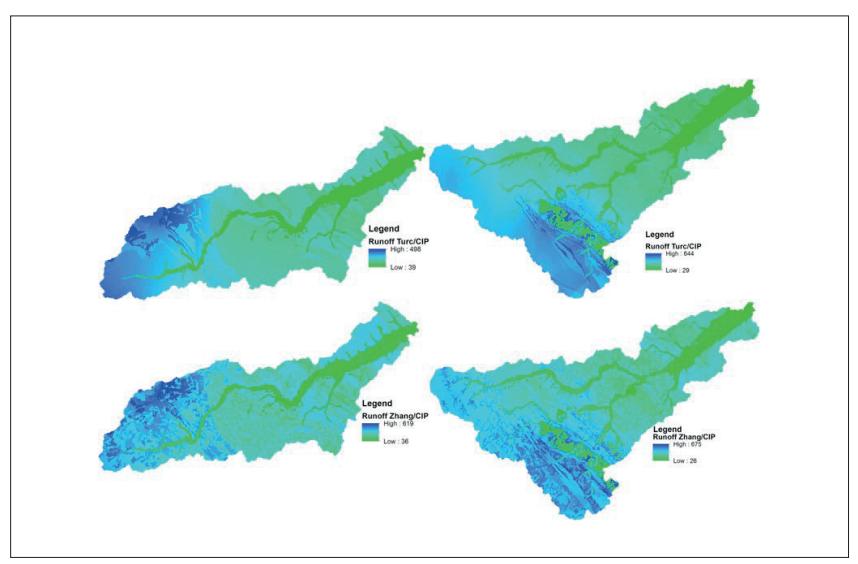

Fig. 5 - Surface runoff maps (1980-2010) calculated in the Foglia (left) and Metauro (right) watersheds.

Fig. 5 - Carte del deflusso superficiale (1980-2010) calcolate nei bacini del Foglia (sinistra) e del Metauro (destra).

De Angelis (2006), evidencing a similar reduction in the Candigliano river between the 1970's and the 1991-2000 average runoff; such decrease is strongly related to the shorter duration of mid to high-flow events typical of the watersurplus winter season. Preliminary observations in the last few years (2011-2015) suggest a new quite significant increase of runoff, more evident in low permeability basins (Foglia, Metauro), where hypodermic runoff and shallow and/or perched aquifers' discharge play an important role.

In the Candigliano subwatershed, on a mainly carbonate bedrock, comparison between the two reference periods shows that Summer base-flow is much less affected by the effective precipitation decrease. Such base-flow is fed by the above mentioned important carbonate mountain aquifers and makes up the largest part of groundwater discharge from the

Tab. 2 - . Comparison between historical SIMN average runoff and 1980-2010 estimated surface runoff, obtained from Turc/CIP metbod, from CN-based simulation and direct flow measures (*: from average runoff 2007-2010); calculated surface runoff is added to base-flow, estimated from recent measurements taken in the 2000-2010 decade (Grey: impermeable basin; light grey semipermeable basin; white: carbonatic basin).

Tab. 2 - Confronto tra il deflusso medio annuo storico (SIMN) e le stime di deflusso superficiale del periodo 1980-2010, calcolato da metodica Turc/CIP, da simulazione con metodo CN e da misure dirette (*: da portata media 2007-2010); il deflusso calcolato viene incrementato con il deflusso di base, stimato da misure sperimentali recenti (2000-2010).

\begin{tabular}{|c|c|c|c|c|c|c|}
\hline $\begin{array}{c}\text { Basin } \\
\text { (runoff-gauge station } \\
\text { - basin's area in } \mathrm{km}^{2} \text { ) }\end{array}$ & $\begin{array}{c}\mathbf{P} \\
1980-2010 \\
\mathrm{~mm} / \mathrm{y}\end{array}$ & $\begin{array}{c}\text { ETR (Turc) } \\
1980-2010 \\
\mathrm{~mm} / \mathrm{y}\end{array}$ & $\begin{array}{c}\text { ETR (Lu) } \\
1980-2010 \\
\mathrm{~mm} / \mathrm{y}\end{array}$ & $\begin{array}{l}\text { Average SIMN } \\
\text { historicall mean year } \\
\text { total runoff (1925- } \\
\text { 1975) } \mathrm{mm} / \mathrm{y}\end{array}$ & $\begin{array}{c}\text { Turc/CIP } \\
\text { calculated surface } \\
\text { runoff }(1980-2010) \\
+ \text { measured summer } \\
\text { base-flow, } \mathrm{mm} / \mathrm{y}\end{array}$ & $\begin{array}{c}\text { Hystorical/recent } \\
\text { specific measured } \\
\text { summer base-flow } \\
\left(\mathrm{L} / \mathrm{s} / \mathrm{km}^{2}\right)\end{array}$ \\
\hline $\begin{array}{l}\text { Foglia (Montecchio - } \\
\left.602 \mathrm{~km}^{2}\right)\end{array}$ & 883 & 581 & 535 & 384 & $249+1$ & $<0.05 /<0.05$ \\
\hline $\begin{array}{l}\text { Metauro (Calmazzo - } \\
373 \mathrm{~km}^{2} \text { ) }\end{array}$ & 990 & 574 & 583 & 582 & $271+8.5$ & $0.34 / 0.27$ \\
\hline $\begin{array}{l}\text { Upper Metauro (Curve } \\
\text { Number simulated- } \\
\text { basin, Fig. 6) }\end{array}$ & 1074 & 669 & 635 & ungauged & 386 (total) & n.a. \\
\hline \multirow{2}{*}{$\begin{array}{l}\text { Candigliano } \\
\text { (Acqualagna -618 km²) }\end{array}$} & \multirow{2}{*}{1115} & \multirow{2}{*}{562} & \multirow{2}{*}{590} & \multirow{2}{*}{705} & $444 *$ total, measured & \multirow{2}{*}{$1.50 / 1.32$} \\
\hline & & & & & $353+41.6$ & \\
\hline
\end{tabular}




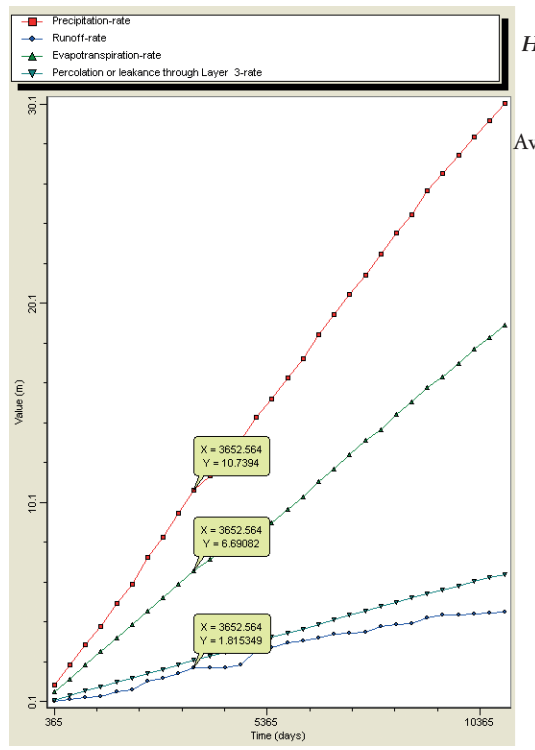

Marnoso-arenacea aquifer

Hydrologic simulations $-1 D$ model $\mathrm{P}=1074 \mathrm{~mm} / \mathrm{y}$

$\operatorname{Tm}=12.5^{\circ} \mathrm{C}$

Average basin's gradient : $60 \%\left(1^{\circ}\right)$

Average versant lenght : $1000 \mathrm{~m}$

Permeability range:

$1.0 \times 10^{-3} \mathrm{~cm} / \mathrm{s}$ ( cover)

$1.0 \times 10^{-4} \mathrm{~cm} / \mathrm{s}$ ( bedrock )

$\mathrm{ETR}=669 \mathrm{~mm} / \mathrm{a}$

$\mathrm{PE}=405 \mathrm{~mm} / \mathrm{a}$

$\mathrm{P}=\mathrm{ETR}+\mathrm{R}+\mathrm{Ie}+\mathrm{Iep}$

(in $\mathrm{mm} / \mathrm{y}$ )

$1074=669+181+205+20$

$$
\text { ( in \%) }
$$

$100=62.2+16.9+19.1+1.8$

Surf. Runoff: $12.21 / \mathrm{s} / \mathrm{km}^{2}$

Infiltration $(\mathrm{z}=-3.70 \mathrm{~m})$ :

$6.5 \mathrm{l} / \mathrm{s} / \mathrm{km}^{2}$

“Deep Infiltration”(bedrock): $0.6 \mathrm{l} / \mathrm{s} / \mathrm{km}^{2}$

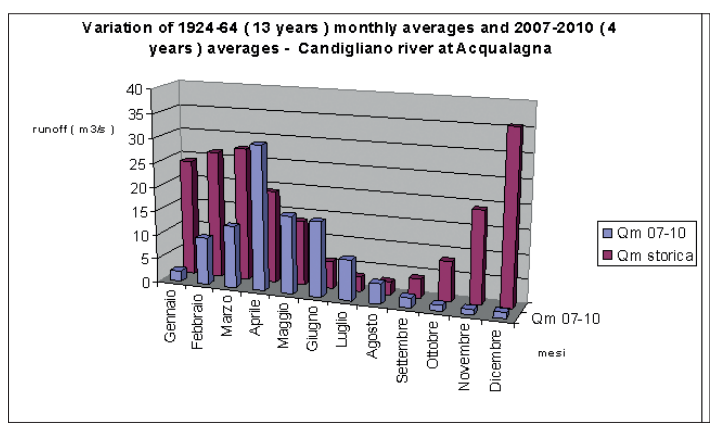

Fig. 7 - Runoff variation in Candigliano river at Acqualagna: comparison between bistorical (1924-1964) montbly averages and short-term recent averages (20072010), Farina (2013).

Fig. 7 - Variazioni di deflusso del F. Candigliano ad Acqualagna: confronto tra medie mensili storiche (1924-64) e medie di breve periodo (2007-2010), Farina 2013.

Catria-Nerone carbonatic range through the so-called linear springs (Boni et al. 1986, Farina and Gerboni, 1994). The Effective Infiltration (EI) estimates of the single aquifers are summarized in Tab. 3. In Alluvial aquifers direct Effective Infiltration was estimated with P.I.Cs, while in the hills' and mountain aquifers a comparison between EI derived from groundwater discharge measures and Infiltration derived from P.I.Cs is possible.

Fig. 6 - Hydrologic simulation on upper Metauro watershed with Curve Number method implemented on a yearly basis and 30 years simulation interval. Data expressed in meters ( $y$ axis).

Fig. 6 - Simulazione idrologica sull'alto bacino del $\mathrm{f}$. Metauro con il metodo Curve Number su base annua, mediante curve cumulate e periodo di simulazione di 30 anni. Dati idrologici espressi in $\mathrm{m}$ (asse $\mathrm{y}$ ).

Tab. 3 - Values of Effective Precipitation and estimates Effective Infiltration of the aquifers, (Fig. 1) and P.I.C factors applied to the main lithological units.

Tab. 3 - Valori della Precipitazione efficace (ETR calcolata con Turc) e stime della Infiltrazione efficace degli acquiferi (cfr. Fig. 1) e Coefficienti di Infiltrazione Potenziale attribuiti alle principali unità litologiche.

\begin{tabular}{|c|c|c|c|c|}
\hline Aquifers & $\begin{array}{c}\text { Effective Precipitation } \\
\text { P-ETR (Turc) } \\
1980-2010, \mathrm{~mm} / \mathrm{y}\end{array}$ & $\begin{array}{c}\text { Effective Infiltration Ie } \\
1980-2010, \mathrm{~mm} / \mathrm{y}\end{array}$ & $\begin{array}{c}\text { Potential Infiltration } \\
\text { Coefficient P.I.C. } \\
\text { (adim) }\end{array}$ & Notes \\
\hline Lower valley alluvium & $175-210$ & $160-190$ & 0.9 & $\begin{array}{l}\text { Saturated thickness }>10 \mathrm{~m} \text {, } \\
\text { significant surface water } \\
\text { exchange }\end{array}$ \\
\hline Mio-pliocenic hills & $250-300$ & $50-100$ & $0.2-0.4$ & $\begin{array}{l}\text { Minor local aquifers } \\
\text { (marly,marly limestones) }\end{array}$ \\
\hline Upper valley alluvium & $250-300$ & $225-270$ & 0.9 & $\begin{array}{l}\text { Little thickness, fast surface } \\
\text { water exchanges }\end{array}$ \\
\hline $\begin{array}{l}\text { Val Marecchia Sheet } \\
\text { (Carpegna aquifers and } \\
\text { others) }\end{array}$ & $350-580$ & $175-300$ & 0.5 & $\begin{array}{l}\text { "Alberese" marly limestone } \\
\text { aquifers }\end{array}$ \\
\hline $\begin{array}{l}\text { Marly-Sandstone Flysch } \\
\text { aquifers }\end{array}$ & $550-600$ & $135-180$ & $0.25-0.3$ & $\begin{array}{l}\text { Significant hypodermic } \\
\text { runoff }\end{array}$ \\
\hline $\begin{array}{l}\text { Carbonate aquifers } \\
\text { (Furlo-Cesane mnt.) }\end{array}$ & $350-400$ & $\begin{array}{c}210-230(\mathrm{SRB}) \\
300(\mathrm{MM})\end{array}$ & $\begin{array}{l}0.6(\mathrm{SRB}) \\
0.8(\mathrm{MM})\end{array}$ & $\begin{array}{l}\text { SRB: Scaglia Rossa e } \\
\text { Bianca aquifer MM: Calcare } \\
\text { Massiccio e Maiolica } \\
\text { aquifers }\end{array}$ \\
\hline $\begin{array}{l}\text { Carbonate aquifers } \\
\text { (Catria-Nerone ridge ) }\end{array}$ & $\begin{array}{c}500-600(\mathrm{SRB}) \\
850(\mathrm{MM})\end{array}$ & $\begin{array}{l}250-350(\mathrm{SRB}) \\
700-750(\mathrm{MM})\end{array}$ & $\begin{array}{c}0.6(\mathrm{SRB}) \\
0.85(\mathrm{MM})\end{array}$ & $\begin{array}{l}\text { SRB's measured Ie }<\text { Ie } \\
\text { calculated with PIC }\end{array}$ \\
\hline
\end{tabular}


The silting process of the existing reservoirs: a preliminary analysis

The preliminary analysis of erodibility was performed in watersheds' sectors upgradient the main reservoirs: S. Lazzaro and Tavernelle dams in the Metauro river and Furlo dam in its main tributary, the Candigliano river; Mercatale dam in the Foglia basin. Retained sediments' volumes in reservoirs were considered (Tabs. 4-5): although time series are not homogeneous, estimates show a high average volume retention $\left(\mathrm{m}^{3} / \mathrm{y}\right)$ in the Metauro's reservoirs, due to its larger watershed and precipitations, but Mercatale, in the upper Foglia watershed, has the highest specific retention $\left(\mathrm{m}^{3} /\right.$ $\mathrm{km}^{2} / \mathrm{y}$ ). Estimates based on topographic surveys carried out by ISMES indicate a volume reduction of $59.600 \mathrm{~m}^{3} / \mathrm{y}$ in the whole three subsequent basins of Furlo, S.Lazzaro and Tavernelle, caused by sediments cumulated from 2001 to 2009. The estimate is fairly close to that provided by AATO1, giving an overall capacity reduction of $50,000 \mathrm{~m}^{3} / \mathrm{y}$ in the same reservoirs. Watershed specific erosion rates varies from $0.52 \mathrm{~mm} / \mathrm{y}$ upvalley Mercatale, to $0.2-0.3 \mathrm{~mm} / \mathrm{y}$ at Furlo dam's section and $0.3-0.4 \mathrm{~mm} / \mathrm{y}$ at $\mathrm{S}$. Lazzaro. Beside, a sharp yearly sediment retention's decrease at Furlo dam over time (2001-2009 period, compared to the $1920-1973$ period) should be noticed.

Tab. 4 - Original capacity and recent residual volumes in reservoirs at dams on the Metauro/Candigliano (green) and Foglia (yellow) rivers. Metauro's estimates taken from AATO 1 were collected by ISMES. * gross volume, datum taken from Pesaro-Urbino Province 1973.

Tab. 4 - Volumi originari e residuali negli invasi del Metauro/Candigliano (in verde) e del Foglia (in giallo). I dati del Metauro, forniti da AATO1, sono misurati da ISMES.

\begin{tabular}{|c|c|c|c|c|}
\hline $\begin{array}{c}\text { Basins } \\
\text { (year of construction) }\end{array}$ & $\begin{array}{l}\text { Original Net volume } \\
\qquad\left(\mathrm{m}^{3}\right)\end{array}$ & $\begin{array}{c}\text { Net volume in } 1970 \\
\left(\mathrm{~m}^{3}\right)\end{array}$ & $\begin{array}{l}\text { Net volume } 2009 \\
\left(\mathrm{~m}^{3}\right)\end{array}$ & $\begin{array}{c}\text { Annual average } \\
\text { sediment retention } \\
\left(\mathrm{m}^{3} / \mathrm{y}\right)\end{array}$ \\
\hline Furlo (1920) & $2,000,000 *$ & 750,000 & 320,000 & $\begin{array}{c}17,680(1920-73) \\
8600 \mathrm{~m}^{3} / \mathrm{y}(2001-2009)\end{array}$ \\
\hline S.Lazzaro (1959) & 840,000 & & 499,000 & $14,000(2001-2009)$ \\
\hline Tavernelle (1964) & $1,225,000$ & & 598,000 & $37,000(2001-2009)$ \\
\hline Total & & & & $59,600 \mathrm{~m}^{3} / \mathrm{y}(2001-2009)$ \\
\hline Mercatale (1974) & $5,700,000$ & & $\begin{array}{c}4,900,000 \\
(2013)\end{array}$ & $20,000 \mathrm{~m}^{3} / \mathrm{y}(1974-2013)$ \\
\hline
\end{tabular}

Tab. 5 - Parametric and experimental estimates of suspended and bed-load sediments transport in the Metauro and Foglia basins (Gazzolo and Bassi 1961, CESI 2001, modified). Tab. 5 - Stime parametriche e dati sperimentali del trasporto torbido e di fondo nei bacini del Metauro e del Foglia.

\begin{tabular}{|c|c|c|c|}
\hline \multirow[b]{2}{*}{ Rivers } & \multicolumn{2}{|c|}{$\begin{array}{l}\text { Specific suspended sediment load } \\
\qquad\left(\mathrm{m}^{3} / \mathrm{Km}^{2} / \mathrm{y}\right)\end{array}$} & \multirow{2}{*}{$\begin{array}{c}\begin{array}{c}\text { Specific bed load } \\
\left(\mathrm{m}^{3} / \mathrm{K} \mathrm{m}^{2} / \mathrm{y}\right)\end{array} \\
\text { Estimates } \\
\text { (from Province, 1973) }\end{array}$} \\
\hline & $\begin{array}{c}\text { Estimated } \\
\text { (from torbidity measures) }\end{array}$ & $\begin{array}{c}\text { Estimated } \\
\text { (from parametric formulas) }\end{array}$ & \\
\hline $\begin{array}{l}\text { Metauro } \\
\text { (Bellaguardia) }\end{array}$ & 502 & $543^{*}$ & 296 \\
\hline $\begin{array}{l}\text { Foglia } \\
\text { (Montecchio) }\end{array}$ & 939 & $1223 *$ & 265 \\
\hline \multicolumn{4}{|c|}{ Note (At bulk density of $1.6 \mathrm{t} / \mathrm{m}^{3}$ ) } \\
\hline
\end{tabular}

\section{Discussion}

The decrease of average surface runoff is quite clear, although not precisely determined, most likely for inhomogeneity of direct and indirect estimates on a temporal and spatial base. In the Candigliano basin 2007-2010 precipitation averages are slightly lower (-1\%) than the long term 1980-2010 data, so the available runoff data, although very limited in time, are still quite significant and indicative of a runoff decrease, compared to the old SIMN averages. On the other hand it should be noticed that the indirect Turc/CIP method, which estimates surface runoff, cannot take into account the groundwater seepage flowing back to rivers, which makes up a significant part of total runoff in permeable and semipermeable basin (Boni et al. 1995), as suggested by a preliminary application of the Curve Number method in a simulated mountain basin. A gross estimate of $-35 \%$ decrease of average runoff is deemed probable for most basins, and it is clearly related to the total and net precipitation reduction over the Province of Pesaro- 
Urbino during the post-war period. Nevertheless a significant influence of land-use variation, especially in the more rainy mountain areas is deemed probable: runoff decrease not only depends on the climate change but also on the expansion of forest land observed during the past decades in the mountain areas, both affecting the Runoff Coefficient. Woodland has a great influence on the formation of runoff, regarding soilwater consumption during the vegetative season, rainfall interception, water and topsoil retention (Scarascia Mugnozza et al. 1988). That is particularly evident in strongly sloping, less permeable catchments, particularly subject to runoff and erosion. In carbonate watersheds Summer base-flow remains quite steady through the decades; that is clearly related to a significant groundwater discharge from the major carbonate complex of the Appennines range (Calcare Massiccio and Maiolica aquifers), expecially within the Bosso and Burano creeks (Candigliano sub-basin), where the largest outcrops of such complex are (Farina and Gerboni 1994, Caprari and Nanni 1999). The Effective Infiltration of the Scaglia Rossa e Bianca aquifer in the same area is less than expected, compared to regional estimates carried out in southern Marche and Umbria (Boni et al. 1986), in agreement with Mastrorillo and Petitta (2010). Carbonate aquifers represents the main resource of groundwater for future generations and its use is regulated/ restricted by Marche Region Water Protection Plan or PTA (Marche Region 2007-2008). The Minimum Flow set by PTA seems not to match the actual runoff conditions, being based on historical climatic and hydrometric data that have changed over time. Minimum flow thus calculated is in many cases higher than the natural flow actually measured in the same gauging station. Therefore, to set up-to-date minimum river flows a modification of the hydrological part of the PTA's parametric formula may be suggested: a preliminary value of Specific Runoff, of $1.0 \mathrm{~L} / \mathrm{s} / \mathrm{km}^{2}$ (from which Minimum Flow is derived), is proposed for most rivers of the Province, except for the Bosso-Burano sub-catchments, where the present regulated value of $1.6 \mathrm{~L} / \mathrm{s} / \mathrm{km}^{2}$ seems suitable.

As for rivers' sediments bed-load and reservoirs' volume reduction the preliminary analysis evidences substantial differences between Candigliano (in a mainly mountain and carbonate watershed) and Foglia rivers, the latter draining a mainly hilly and impermeable territory: the first is characterized by lower overall erodibility, together with a higher sediment transport potential, while in the Foglia basin an opposite tendency is shown. Metauro river, downvalley the Candigliano confluence, has an intermediate behaviour, reflecting the geological and morphological differences of its two sub-basins (Tabs. 4-5).

\section{Conclusions}

The study showed a significant reduction of yearly average stream flow in the Province of Pesaro-Urbino, due both to climate change and land-use variations in the past decades. The availability of surface water, on which the local watersupply system is mostly based, is a critical issue in Summer periods, when different water uses and environmental constraints come to conflict, as verified in particularly dry years $(2003,2007,2011)$, when drink water supplies came at risk. The analysis carried out shows the high potential of carbonate Maiolica and Calcare Massiccio aquifers, whose large saturated volume tends to mitigate the precipitations' changes. As the climate change increases vulnerability of water-supply systems, an adaptative process is needed, urging to achieve a new equilibrium between surface and groundwater. For drink-water purposes, the role of carbonate aquifers, so far basically underexploited, must be reconsidered: in the mid term, the latter may be allocated to feed the aqueducts system in summer periods, while referring to the existing surface water supplies during the water-surplus period. In any case a gradual reduction of surface water supplies should be considered, replaced by a monitored exploitation of good quality groundwater through deep wells, particularly in the summer season. Volume recovery works in the existing reservoirs by sediments excavation does not seem to be a long-term solution: due to the present still high erodibility of impermeable watersheds, such works may have benefits limited in time, should be regarded as maintenance works and, if maintenance is absent or limited, may be considered as short-term or emergency solutions. Larger projects evidence critical economical and environmental aspects and should be evaluated together with other feasible alternatives. Significant long-term efforts in achieving land-use changes should be considered first, especially in the Foglia watershed; that implies political strategy and communication, the involvement of stakeholders and the capability of implementing effective planning and management actions. 


\section{REFERENCES}

AATO 1 Marche Nord (2010) Progetto per la redazione del piano d'ambito "Water plan of the Marche Nord water autority". Autorità di Ambito Territoriale Ottimale, Pesaro.

Armiraglio S, Cerabolini B, Gandellini F, Gandini P, Andreis C (2003) Calcolo informatizzato del bilancio idrico del suolo "Natura Bresciana" "Digitized evaluation of the hydraulic balance of soil "Natura Bresciana”. Ann Mus Civ Sc Nat Brescia 33:209-216.

ASSAM - Agenzia Servizi Settore Agroalimentare delle Marche (2006) Suoli e paesaggi delle Marche "Soils and landscapes of Marche". ASSAM, Ancona.

Boni C, Bono P, Capelli G (1986) Schema idrogeologico dell'Italia Centrale "Hydrogeologic scheme of Central Italy". Mem Soc Geol It 35:9911012.

Boni C, Mastrorillo L, Petitta M (1995) Scomposizione della portata dei corsi d'acqua dell'Appennino Marchigiano con il metodo delle "Portate mensili caratteristiche" "Decomposition of rivers runoff in the Marchesan Appennine with the "characteristic monthly flow" method". Proceedings of the $3^{\text {rd }}$ National Congress of Young Researchers in Applied Geology, Potenza, 28-30 October 1993. SAFRA ed., Bari.

Caprari M, Nanni T (1999) Idrogeologia della dorsale carbonatica del M. Catria-M. Nerone (Appennino umbro-marchigiano settentrionale) "Hydrogeology of the Catria-Nerone carbonate ridge". Boll Soc Geol It 118:563-584.

Cavitolo P (2014) Valutazione delle potenzialità delle risorse idriche nella Provincia di Pesaro-Urbino e scenari di sostenibilità in relazione al bilancio idrico provinciale. Tesi di Dottorato "Evaluation of water resources' potential and sustainabily scenarios, related to the provincial water balance" Phd Thesis. University of Urbino Carlo Bo, Urbino.

Centro di Ecologia e Climatologia-Osservatorio Geofisico Sperimentale di Macerata (2002) Campo medio della precipitazione annuale e stagionale sulle Marche per il periodo 1950-2000, "Average yearly and seasonal precipitations in Marche Region from 1950 to 2000". Osservatorio Geofisico Sperimentale di Macerata, Macerata.

CESI (2001) Metodologie indirette di valutazione del trasporto solido a monte di alcuni invasi idroelettrici campione rappresentativi di aree alpine ed appenniniche "Indirect methods for evaluating rivers' sediments load upvalley hydroelectric reservoirs in Alpine and Apennine areas". Cesi S.p.a., Milan.

Civita M (1973) L'infiltrazione potenziale media annua nel massiccio del Matese (Italia Meridionale) "Potential yearly average infiltration in the Matese Massif (Southern Italy)". Proceedings $2^{\text {nd }}$ International Congress on Groundwater, Palermo.

De Angelis S (2006) Cartografia ed analisi geologiche attraverso l'impiego dei sistemi geografici informativi, Tesi di Dottorato "Cartography and geological analysis through the use of GIS", Phd Thesis. University of Urbino Carlo Bo, Urbino.

European Commission (2012) Available from: ec.europa.eu/environment/water/blueprint/index_en.htm

Farina D (2013) Analisi idrogeologica e valutazione delle risorse idropotabili della Provincia di Pesaro-Urbino utilizzabili secondo criteri di sostenibilità ambientale, Tesi di Dottorato "Hydrogeological analysis and assessment of drink-water resources and their sustainable management in the Province of Pesaro-Urbino", Phd Thesis. University of Urbino Carlo Bo, Urbino.

Farina D, Gerboni R (1994) Indagine idrometrica ed idrochimica sulla discarica sorgiva nei corsi d'acqua del settore settentrionale della Dorsale Umbro - Marchigiana (Fiumi Candigliano, Bosso, Burano, Sentino) e considerazioni idrogeologiche sugli acquiferi carbonatici dei Massicci dei Monti Nerone Catria e Cucco "Hydrometric and hydrochemical survey on groundwater discharge into streams of the northern Umbro-marchesan ridge, Nerone-Catria-Cucco massifs". Memoir of $7^{\text {th }}$ Congress of the National Council of Geologists, Rome.
Farina D, Severini A (2013) Towards a more sustainable use of water resources through an integrated management of surface water and groundwater. IAH International Congress 2013, Perth.

Ferrara V (2007) Le conseguenze in area mediterranea ed in Italia "Climate change: consequences in the Mediterranean area and in Italy". Proceedings of National Congress Climate change, 12-13 September 2007, Rome.

Gazzolo T, Bassi G (1961) Relazione fra i fattori del processo di ablazione ed il trasporto solido in sospensione nei corsi d'acqua italiani "Relation among the factors of ablation and suspended sediments transport in Italian streams". Giornale del Genio Civile 1:377-395.

Gentilucci M, Bisci C, Fazzini M, Vaccaro C (2015) Time and space distribution of precipitation in the Marche Region (Central Italy): preliminary observations. Proceedings of the $23^{\text {rd }}$ ICAM Congress, Innsbruck.

ISPRA (2016) Gli indicatori del clima in Italia nel 2015 "Climatic indicators in Italy in 2015”. Istituto Superiore per la Protezione e la Ricerca Ambientale, Rome

Lu Zhang, Potter N, Nickel K, Zhang Y, Shao Q (2008) Water balance modeling over variable time scalesbased on the Budyko framework. Model development and testing. Journal of Hydrology 360:117-131.

Marche Region (2007-2008) Piano di tutela delle acque "Water protection plan". Regione Marche, Ancona.

Marche Region (2016). Sistema Informativo Regionale Meteo IdroPluviometrico "Regional Hydro-meteo system website". Available from: http://84.38.48.145/sol/indexjs.php?lang=it

Marchetti M, Bertani R, Corona P, Valentini R (2012) Cambiamenti di copertura forestale e dell'uso del suolo nell'inventario dell'uso delle terre in Italia "Woodland and soil-use changes in Italy" Forest@ 9:170-184

Mastrorillo L, Petitta M (2010) Effective infiltration variability in the Umbria-Marche carbonate aquifers of central Italy. Journal of Mediterranean Earth Sciences 2:9-18.

Molinari C, Lipparini T, Bassi G (1971) Risorse idriche delle Marche "Water Resources of Marche Region" Ente di Sviluppo nelle Marche, Ancona.

Pesaro-Urbino Province (1973) Studio geologico, climatico, morfologico, idrologico, in funzione della stabilità del suolo e per la salvaguardia del paesaggio e dell'ambiente naturale della Provincia di Pesaro-Urbino. Pesaro-Urbino Province, Pesaro, "Geologic, climatic, morphologic, hydrologic study aimed to soil stability and safeguard of the environment in the Pesaro-Urbino Province".

Rusco E, Tiberi M (2009) Case study - Italy. Sustainable Agriculture and Soil Conservation (SoCo Project) Publications Office of the European Union. Joint Research Centre, European Soil Data Centre, Brussels. Available from: esdac.jrc.ec.europa.eu/projects/SOCO/ Case\%20Studies/casestudyIT_002.pdf

Scarascia Mugnozza G, Valentini R, Spinelli R, Giordano E (1988) Osservazioni sul ciclo dell'acqua in un bosco ceduo di Quercus cerris "Observations on the water cycle in a $Q$. cerris coppice wood". Annali dell'Accademia Italiana di Scienze Forestali 37:3-21.

Thorntwaithe CV, Mather JR (1957) Instructions and tables for computing potential evapotranspiration and the water balance. Publications of Climatology 10(3):185-311.

Turc L. (1955) Le bilan d'eau des sols. Relations entre les precipitations, l'evaporation et l'ecoulement. Ann. Agron.,1

Waterloo Hydrogeologic (2004) WHI Unsat Suite Plus. User manual. Waterloo Hydrogeologic, Kitchener, ON. 